\title{
Utilization of Nematode-infected Pinewood for Mushroom Cultivation and Production of Reducing Sugar
}

\author{
ChenYan Huang, ${ }^{\mathrm{a}, 1}$ Xuan Wu, ${ }^{\mathrm{a}, \mathrm{b}, 1}$ XiaoYi Dai, ${ }^{\mathrm{a}}$ Rebeca Carballar-Lejarazú, ${ }^{\mathrm{c}}$ \\ YongXin Tao, ${ }^{\mathrm{d}}$ JianRong Wen, ${ }^{\mathrm{e}}$ Ren Chen, ${ }^{\mathrm{f}}$ FeiPing Zhang, ${ }^{\mathrm{a}, *}$ and SongQing Wu ${ }^{\mathrm{a}, *}$ \\ To improve the nematode-infected pinewood application value, an \\ effective strategy was developed based on the cultivation of Flammulina \\ velutipes to process the pinewood that was infected by the nematode \\ Bursaphelenchus xylophilus. Different treatments were compared to \\ determine the optimal method to obtain the highest yields of reducing \\ sugars. The results showed that the cultivation of $F$. velutipes using the \\ nematode-infected pine sawdust overcame the disadvantage of cultivation \\ by using healthy pine sawdust, and whether fungal infection that happened \\ in the period of pine wilt disease or during the cultivation of $F$. velutipes \\ both can contribute on the degradation of the polysaccharide content. A \\ high yield of reducing sugars can be obtained using $2 \%$ dilute sulfuric acid \\ at $121^{\circ} \mathrm{C}$ for $1 \mathrm{~h}$ to treat recyclable nematode-infected pine sawdust after \\ the cultivation of $F$. velutipes. Additionally, the results showed that fungal \\ infection that occurred in the period of the pine wilt disease and during the \\ cultivation of $F$. velutipes in addition to acid hydrolysis effectively \\ converted hemicellulose to reducing sugars.
}

Keywords: Nematode-infected pinewood; Flammulina velutipes cultivation; Acid hydrolysis; Reducing sugars

Contact information: a: Key Laboratory of Integrated Pest Management in Ecological Forest, Fujian Province University, College of Forestry, Fujian Agricultural and Forestry University, Fuzhou, 350002, China; $b$ : College of Environment and Ecology, Xiamen University, Xiamen, 361000, China; $c$ : Department of Microbiology and Molecular Genetics, University of California Irvine, Irvine, CA 92697 USA; d: China National Engineering Research Center of JUNCAO Technology, Fujian Agriculture and Forestry University, Fuzhou, 350002, China; e: Longyan Customs, Longyan, 364000, China; f: Putian Entry-exit Inspection and Quarantine Bureau, Putian, 351100, China; 1: These authors contributed equally to this work; *Corresponding author: fpzhang1@163.com, dabinyang@126.com

\section{INTRODUCTION}

The pine wilt disease is caused by the Bursaphelenchus xylophilus nematode. This devastating disease results in a large area of pine trees (Pinus massoniana) dying. There are more than one million trees of $P$. massoniana that have been infected since 1982 (Shi et al. 2008). Pine wilt disease has a strong transmission and destruction index, which leads to millions in economic losses. Currently, the main direct and effective strategy to control the pine wilt disease is to discover the infected pine trees in real-time that are felled immediately to prevent the dispersion of the disease to the surrounding healthy trees. However, the lack of proper treatment of the felled trees can cause a secondary transmission of the disease (Jiang et al. 2001). Therefore, it is important to find an effective method to deal with a large number of felled infected pine trees and prevent a secondary spreading. 
Currently, the main remediation methods for the nematode-infected wood are fumigation, local incineration, heat, and microwave treatment (Song et al. 1994; Jiang et al. 2006; Gan et al. 2010). Although these remediation methods are effective and can reduce some losses, they also cause serious pollution effects on the environment and consume a lot of energy. In contrast, other methods are environmentally friendly, such as wood rot bacteria decomposition (Chen et al. 2008) and using the nematode-infected pinewood as a substrate to cultivate Poria cocos (Wu 2013). This last method suggests that the nematode-infected pinewood can be used for edible fungus cultivation. Moreover, sawdust from the nematode-infected pinewood is abundant in cellulose and hemicellulose and it can be used as a substrate to grow edible filamentous fungus ( $\mathrm{Lu}$ et al. 2016). Flammulina velutipes is one of the main edible fungi with high nutritional and medicinal value (Yu et al. 2004). However, healthy pine sawdust cannot be directly used to cultivate the $F$. velutipes due to the effect the pine wood terpenoids (Chen et al. 2002). Alternatively, cultivation of $F$. velutipes by using nematode-infected pinewood is feasible because the terpenoids content of the nematode-infected pinewood is lower than in the healthy pinewood (Kuroda 1989). If the nematode-infected pine sawdust is used for the cultivation of $F$. velutipes, it can effectively prevent the spread of $B$. xylophilus and greatly improve the utilization rate of nematode-infected pinewood and help to reduce the cost of $F$. velutipes cultivation.

While $F$. velutipes cultivation can effectively improve the utilization rate of the nematode-infected pine sawdust, in contrast, the spent mushroom substrate will still have a certain impact on the environment. If the efficient recycling mechanism of nematodeinfected pine sawdust can be established, it will be beneficial to overcome the disadvantages of traditional methods and gain new profits. It has been reported that reducing sugar can be obtained using the biomass conversion method to treat spent mushroom substrate (Wu et al. 2013). The method can degrade lignin or hemicellulose on the surface of the material to realize the conversion of cellulose into reducing sugar, thereby increasing the yield of reducing sugar. Therefore, finding the suitable conditions for the conversion of nematode-infected pine sawdust into reducing sugar will contribute in developing a sustainable method to treat nematode-infected pinewood based on the reutilization of the infected materials.

In this study the authors used broad-leaved wood sawdust, healthy pine sawdust, and nematode-infected pine sawdust to cultivate $F$. velutipes, and the feasibility of growing $F$. velutipes was evaluated by comparing the yield of $F$. velutipes. The reducing sugar yield was analyzed by using different material sources (healthy pine sawdust and nematodeinfected pine sawdust, healthy pine substrate, and nematode-infected pine substrate) under different treatments (acid, alkali, and water treatment). The healthy pine substrate and nematode-infected pine substrate refer to a type of spent mushroom substrate. The healthy pine and nematode-infected pine substrates are made from using the healthy pine sawdust and nematode-infected pine sawdust to cultivate $F$. velutipes, respectively. The treatment efficiency was determined using scanning electron microscopy (SEM), X-ray diffraction (XRD), Fourier transforming spectroscopy (FTIR), and X-ray photoelectron spectroscopy (XPS) to analyze the morphological, physical, and chemical structures of the sample surface under the same treatment conditions. The data provide insight into a more economical and environmentally friendly method and a high-efficiency recycling process for the use of the nematode-infected pinewood. 


\section{EXPERIMENTAL}

\section{Materials}

Cultivation of $F$. velutipes

Infected pinewood and healthy pinewood were both collected from Minhou County, Fuzhou City (Fujian Province, China). All nematode-infected pinewood samples used in this research had been previously ground. The substrate ingredients for growing $F$. velutipes contain $58 \%$ cottonseed shell, $20 \%$ wood sawdust, $20 \%$ bran, $1 \%$ gypsum, and $1 \%$ sucrose. The dry material weight was $270 \mathrm{~g}$ for each sample (broad-leaved wood sawdust, healthy pine sawdust, and nematode-infected pine sawdust); $90 \mathrm{~g}$ of each material was put in bottles in triplicate. The bottles containing the materials were sterilized $\left(121^{\circ} \mathrm{C}\right.$, $4 \mathrm{~h}, 103.4 \mathrm{KPa}$ ) and then inoculated with $F$. velutipes FL19 and cultivated at $25{ }^{\circ} \mathrm{C}$. After the mycelium grew and covered the material, it was kept in culture at $10{ }^{\circ} \mathrm{C}$ and at 80 to $90 \%$ humidity until the harvesting time (stipe length of $15 \pm 2.5 \mathrm{~cm}$ and a cap diameter of $0.9 \pm 0.2 \mathrm{~cm}$ ). The fresh weight of $F$. velutipes was recorded immediately after harvest. The average mushroom yield of each bottle was recorded and analyzed. Finally, the spent mushroom substrate was recycled for later experiments.

\section{Methods}

Different hydrolysis treatment and composition detection

After air drying $\left(60{ }^{\circ} \mathrm{C}, 72 \mathrm{~h}\right)$, each substrate (healthy pine sawdust, nematodeinfected pine sawdust, healthy pine substrate, and nematode-infected pine substrate) was milled with a grinder to pass through a 40-mesh screen (425 um). Different treatment conditions were set using different chemicals, concentrations, and temperature to determine the optimal conditions that resulted in higher yields. The reaction conditions included acid hydrolysis (concentration 0.5 to $4 \%$ and 50 to $121{ }^{\circ} \mathrm{C}, 1 \mathrm{~h}$ ), alkaline hydrolysis (concentration $\left.1 \%, 121^{\circ} \mathrm{C}, 1 \mathrm{~h}\right)$, and water treatment $\left(121^{\circ} \mathrm{C}, 1 \mathrm{~h}\right)(\mathrm{Wu}$ et al. 2013). Reactions were performed by adding $5 \mathrm{~g}$ of the substrate to each chemical at $1: 10$ ratio (solid : liquid) in a $250-\mathrm{mL}$ conical flask. After the above reaction was finished, the mixed solution was allowed to cool, followed by the addition of the corresponding concentration of $\mathrm{H}_{2} \mathrm{SO}_{4}$ or $\mathrm{NaOH}$ to neutralize the mixture solution $(\mathrm{pH}=7)$ and stop the reaction. The neutralized samples were washed four times with distilled water followed by centrifugation $\left(8000 \mathrm{r} / \mathrm{min}, 4^{\circ} \mathrm{C}, 5 \mathrm{~min} /\right.$ time $)$. The solid residues were collected and put into an oven at $45^{\circ} \mathrm{C}$ to dry and seal the substrate surface for subsequent experiments. The supernatant was collected for chemical composition analysis and to determine the yield of reducing sugar. The moisture and ash contents of the samples were determined according to the People's Republic of China national standard GB/T 2677.2 (2011) and GB/T 742 (2008), respectively. The contents of cellulose, hemicellulose, acid-soluble lignin (ASL), and acid-insoluble lignin (AIL) were determined according to the National Renewable Energy Laboratory (NREL) analytical procedure (Sluiter et al. 2008). Each sample was performed in triplicate. The content of reducing sugar was determined by highperformance liquid chromatography (HPLC) (Agilent 1260; Agilent Technologies, Shanghai, China) with an Agilent Zorbax SB-C 18 column $(4.6 \mathrm{~mm} \times 250 \mathrm{~mm}, 5 \mu \mathrm{m})$. Chromatographic conditions were $16 \%$ acetonitrile to $84 \% 0.05 \mathrm{~mol} / \mathrm{L}$ ammonium acetate solution and in a wavelength of $245 \mathrm{~nm}$, with a column temperature of $30{ }^{\circ} \mathrm{C}$ and a flow rate of $1.5 \mathrm{~mL} / \mathrm{min}$. 


\section{SEM analysis}

The morphology surface of the solid residues was analyzed by using SEM, field emission SU8010 (Hitachi High-Technologies, Tokyo, Japan). The dried solid powder was put on the clean silicon wafer, and then the metal (gold) spray was used to make the sample detectable (S. S. Aerosols Pvt. Ltd., Haryana, India). Finally, the image was scanned and saved using the SEM software (Microscope Control v5.2.2 build 2898, Hitachi HighTechnologies, Tokyo, Japan).

\section{XRD analysis}

Structure surface changes of the samples were determined by X-ray diffraction. The detection instrument was a Rigaku Ultima IVX XRD (Tokyo, Japan). The sample was dried and added to a clean vessel and then placed on the instrument. The $\mathrm{Cu} \mathrm{K} \alpha$ sample parameter was obtained at $40 \mathrm{kV}$ and $40 \mathrm{~mA}$ from a Bragg angle $(2 \theta)$ of $5^{\circ}$ to $60^{\circ}$ with a step size of $0.02^{\circ}$ and scanning rate of $6 \% \mathrm{~min}$. The crystallinity index $(\mathrm{CrI})$ of initial and treated samples was calculated according to the protocol already described. The CrI was determined using the following Eq. 1,

$$
C r I=\frac{I_{002}-I_{a m}}{I_{002}} \times 100
$$

where $\mathrm{CrI}$ is the cellulose crystallinity index (\%), $I_{002}$ is the adsorption peak intensity of peak 002 at $2 \theta$ of 22.3, and $I_{\mathrm{am}}$ is the minimum intensity height between peaks 002 and 101 at $2 \theta$ of $18^{\circ}$.

\section{FTIR Analysis}

Changes in the chemical composition of the sample surface were analyzed by FTIR. The dried samples were mixed with potassium bromide (mass ratio 1:100). The samples were ground into a powder and then pressurized, followed by analysis with a Nicolet iS10 (Thermo Fisher Scientific, San Diego, CA, USA) with a scanning spectrum range of 400 to $4000 \mathrm{~cm}^{-1}$.

\section{XPS Analysis}

Changes in the content of the main components (polysaccharide, lignin, and surface extracts) were analyzed by XPS. The instrument used was an Escalab 250Xi (Thermo Fisher Scientific, San Diego, CA, USA). The analytical area of the sample was $500 \mu \mathrm{m} \times$ $500 \mu \mathrm{m}$, and the analytical depth was less than $10 \mathrm{~nm}$. The vacuum degree of the analysis was $1 \times 10^{-10}$ mbar. To weaken the effect of binding energy on the XPS test, the C1s peak was set to $284.8 \mathrm{eV}$ to correct the charge. The raw data of the XPS test were processed using the XPSPEAK 4.1 and OriginPro 8 software (Microsoft Corporation, Redmond, WA, USA).

\section{Statistical Analysis}

After the sample treatment and analysis, the samples of each different treatment condition were performed in triplicate, and the data were expressed as mean \pm standard deviation. The analysis of variance (ANOVA) analysis PRISIS 6 (GraphPad software, La Jolla, CA, USA) and SPSS statistical software (Version 19.0, IBM Corp., Armonk, NY, USA) were used to analyze the significance of the difference, and the result, $\mathrm{P}<0.05$, showed that there were significant differences corresponding to different experimental conditions. 


\section{RESULTS AND DISCUSSION}

\section{Comparative Analysis of $\boldsymbol{F}$. velutipes Yield}

To determine the feasibility of cultivating $F$. velutipes on nematode-infected pine sawdust, the yield of $F$. velutipes was compared and analyzed on three different kinds of wood sawdust (broad-leaf wood sawdust, healthy pine sawdust, and nematode-infected pine sawdust). Cultivation of $F$. velutipes on broad-leaf wood sawdust takes 27 days, and 31 days was taken when cultivated on healthy or nematode-infected pine sawdust (Table 1). However, the mycelial growth was sparse when $F$. velutipes was cultivated on healthy pine sawdust. Interestingly, $F$. velutipes yields were different among the substrates, the average yield per bottle was $39.7 \mathrm{~g}$ on broad-leaved wood sawdust, $38.5 \mathrm{~g}$ on nematodeinfected pine sawdust, and $28.6 \mathrm{~g}$ on healthy pine sawdust (Table 1). The observed differences may be because the growth of hyphae can be affected by the number of terpenoids during its cultivation on healthy pine sawdust. In contrast, the yield of $F$. velutipes cultivated in nematode-infected pine sawdust was not significantly different from that cultivated on broad-leaved wood, because the terpenoids can be volatilized more easily after the pinewood was infected by nematode (Kuroda 1989). These results suggest that nematode-infected pine sawdust is suitable for the cultivation of $F$. velutipes and can help to improve the economic value of nematode-infected pinewood.

Table 1. Mycelium Growth and Mushroom Emergence Period on Various Substrate Materials

\begin{tabular}{|c|c|c|c|c|}
\hline Cultivation Materials & $\begin{array}{c}\text { Number of } \\
\text { Cultivation } \\
\text { Days }\end{array}$ & Growth Situation & $\begin{array}{c}\text { Number of } \\
\text { Harvest } \\
\text { Days }\end{array}$ & $\begin{array}{c}\text { Average Yield } \\
\text { Per Bottle (g) }\end{array}$ \\
\hline Broad-leaf Wood Sawdust & 27 & White, thick & 21 & $39.7 \pm 0.67^{\mathrm{a}}$ \\
\hline $\begin{array}{c}\text { Healthy Pine Sawdust } \\
\text { Nematode-infected Pine } \\
\text { Sawdust }\end{array}$ & 31 & White, sparse & 17 & $28.6 \pm 0.72^{\mathrm{b}}$ \\
\hline $\begin{array}{l}\text { Sa, b, c Values statistically significant different }(\mathrm{P}<0.05) \\
\text { White, thick }\end{array}$ & 17 & $38.5 \pm 0.63^{\mathrm{a}}$ \\
\hline
\end{tabular}

\section{Chemical Composition Analysis}

The chemical components of the different substrates under different treatment conditions were determined and compared with some of the most common agricultural wastes. The percentage of polysaccharide (including cellulose and hemicellulose) content in healthy pine sawdust was $54.2 \%$; however, it was lower in nematode-infected pine sawdust (51.5\%), healthy pine substrate (48.4\%), and nematode-infected pine substrate $(50.2 \%)$. In addition, the percentage of lignin content of nematode-infected pine sawdust (29.8\%) was also lower than that of healthy pine sawdust (34.1\%). It can be inferred from the results that the differences were due to the hydrolysis of some cellulose and hemicellulose that occurred during the period of infection by the pinewood nematode and the cultivation of $F$. velutipes, and the hydrolysis may have been caused by the fungal infection. According to Lara et al. (2010) the pine bark composition can be easily digested by fungus. Moreover, some other studies reported that blue-stain fungi often can be found in the nematode-infected pinewood during the period of the pine wilt disease (Mamiya 1983; Song 1993). In contrast, F. velutipes is a fungus, and its cultivation on wood to some degree means that the wood is infected by fungi (Zhao et al. 2017).

Huang et al. (2020). "Nematode-infected pinewood," BioResources 15(4), 8403-8419. 
Table 2. Chemical Composition of Pine Wood Before and After Treatment, and Comparison with Some Agricultural Wastes

\begin{tabular}{|c|c|c|c|c|c|c|}
\hline Item & $\begin{array}{c}\text { Cellulose } \\
(\%)\end{array}$ & $\begin{array}{l}\text { Hemi- } \\
\text { cellulose } \\
(\%)\end{array}$ & $\begin{array}{c}\text { Acid } \\
\text { Soluble } \\
\text { Lignin (\%) }\end{array}$ & $\begin{array}{c}\text { Acid } \\
\text { Insoluble } \\
\text { Lignin (\%) }\end{array}$ & $\begin{array}{c}\text { Water } \\
\text { Content } \\
(\%)\end{array}$ & $\begin{array}{l}\text { Ash } \\
\text { Content } \\
(\%)\end{array}$ \\
\hline $\begin{array}{l}\text { Healthy Pine } \\
\text { Sawdust }\end{array}$ & $\begin{array}{l}46.1 \pm \\
2.77\end{array}$ & $\begin{array}{l}8.1 \pm \\
0.72\end{array}$ & $2.0 \pm 0.07$ & $32.1 \pm 1.96$ & $\begin{array}{l}6.7 \pm \\
0.58\end{array}$ & $0.6 \pm 0.03$ \\
\hline $\begin{array}{c}2 \% \mathrm{H}_{2} \mathrm{SO}_{4} \text {-treated } \\
\text { Healthy Pine } \\
\text { Sawdust } \\
\text { Sa }^{\mathrm{a}}\end{array}$ & $\begin{array}{l}40.2 \pm \\
3.14\end{array}$ & $\begin{array}{l}3.9 \pm \\
0.22\end{array}$ & $1.2 \pm 0.02$ & $30.5 \pm 0.02$ & $\begin{array}{l}7.0 \pm \\
0.40\end{array}$ & $N D^{d}$ \\
\hline $\begin{array}{c}1 \% \mathrm{NaOH} \text {-treated } \\
\text { Healthy Pine } \\
\text { Sawdust }{ }^{\mathrm{a}}\end{array}$ & $\begin{array}{c}30.8 \pm \\
1.69\end{array}$ & $\begin{array}{l}7.3 \pm \\
0.57\end{array}$ & $1.3 \pm 0.01$ & $26.2 \pm 0.26$ & $\begin{array}{l}4.5 \pm \\
0.24\end{array}$ & ND \\
\hline $\begin{array}{l}\text { Water-treated } \\
\text { Healthy Pine } \\
\text { Sawdust }{ }^{a}\end{array}$ & $\begin{array}{c}33.9 \pm \\
2.34\end{array}$ & $\begin{array}{l}7.6 \pm \\
0.45\end{array}$ & $1.4 \pm 0.03$ & $30.8 \pm 0.30$ & $\begin{array}{l}4.8 \pm \\
0.18\end{array}$ & ND \\
\hline $\begin{array}{c}\text { Nematode-infected } \\
\text { Pine Sawdust }{ }^{a}\end{array}$ & $\begin{array}{l}44.1 \pm \\
3.98 \\
\end{array}$ & $\begin{array}{l}7.4 \pm \\
0.61\end{array}$ & $1.3 \pm 0.39$ & $28.5 \pm 2.82$ & $\begin{array}{l}6.2 \pm \\
0.04\end{array}$ & $0.7 \pm 0.01$ \\
\hline $\begin{array}{c}2 \% \mathrm{H}_{2} \mathrm{SO}_{4} \text {-treated } \\
\text { Nematode-infected } \\
\text { Pine Sawdust }{ }^{\mathrm{a}}\end{array}$ & $\begin{array}{l}36.4 \pm \\
1.35\end{array}$ & $\begin{array}{l}3.0 \pm \\
0.21\end{array}$ & $1.3 \pm 0.12$ & $22.9 \pm 1.85$ & $\begin{array}{l}7.3 \pm \\
0.45\end{array}$ & ND \\
\hline $\begin{array}{c}1 \% \mathrm{NaOH} \text {-treated } \\
\text { Nematode-infected } \\
\text { Pine Sawdust }{ }^{\mathrm{a}}\end{array}$ & $\begin{array}{c}41.5 \pm \\
1.48\end{array}$ & $\begin{array}{l}1.7 \pm \\
0.16\end{array}$ & $1.4 \pm 0.04$ & $22.9 \pm 2.14$ & $\begin{array}{l}8.0 \pm \\
0.44\end{array}$ & ND \\
\hline $\begin{array}{c}\text { Water-treated } \\
\text { Nematode-infected } \\
\text { Pine Sawdust }{ }^{\mathrm{a}}\end{array}$ & $\begin{array}{l}33.8 \pm \\
3.37\end{array}$ & $\begin{array}{l}6.7 \pm \\
0.67\end{array}$ & $1.8 \pm 0.08$ & $25.6 \pm 0.43$ & $\begin{array}{l}8.2 \pm \\
0.16\end{array}$ & ND \\
\hline $\begin{array}{l}\text { Healthy Pine } \\
\text { Substrate }^{a}\end{array}$ & $\begin{array}{c}30.7 \pm \\
1.89\end{array}$ & $\begin{array}{c}17.7 \pm \\
1.45\end{array}$ & $1.6 \pm 0.08$ & $35.3 \pm 1.63$ & $\begin{array}{l}1.8 \pm \\
0.12\end{array}$ & $4.0 \pm 0.17$ \\
\hline $\begin{array}{c}2 \% \mathrm{H}_{2} \mathrm{SO}_{4} \text {-treated } \\
\text { Healthy Pine } \\
\text { Substrate } \\
\text { Sa }\end{array}$ & $\begin{array}{c}26.1 \pm \\
0.92\end{array}$ & $\begin{array}{l}8.1 \pm \\
0.78\end{array}$ & $1.1 \pm 0.10$ & $27.3 \pm 0.75$ & $\begin{array}{l}3.5 \pm \\
0.30\end{array}$ & ND \\
\hline $\begin{array}{c}1 \% \mathrm{NaOH} \text {-treated } \\
\text { Healthy Pine } \\
\text { Substrate } \\
\end{array}$ & $\begin{array}{c}21.9 \pm \\
2.01\end{array}$ & $\begin{array}{c}15.4 \pm \\
1.33\end{array}$ & $0.9 \pm 0.02$ & $13.5 \pm 1.30$ & $\begin{array}{l}5.9 \pm \\
0.56\end{array}$ & ND \\
\hline $\begin{array}{l}\text { Water-treated } \\
\text { Healthy Pine } \\
\text { Substrate } \\
\text { a }^{\mathrm{a}}\end{array}$ & $\begin{array}{c}25.1 \pm \\
1.78\end{array}$ & $\begin{array}{c}17.0 \pm \\
1.52\end{array}$ & $1.5 \pm 0.04$ & $28.6 \pm 2.42$ & $\begin{array}{l}4.4 \pm \\
0.37\end{array}$ & ND \\
\hline $\begin{array}{c}\text { Nematode-infected } \\
\text { Pine Substrate }\end{array}$ & $\begin{array}{l}33.7 \pm \\
2.56 \\
\end{array}$ & $\begin{array}{c}16.5 \pm \\
1.36 \\
\end{array}$ & $1.6 \pm 0.06$ & $35.6 \pm 0.77$ & $\begin{array}{l}1.9 \pm \\
0.12\end{array}$ & $3.6 \pm 0.20$ \\
\hline $\begin{array}{c}2 \% \mathrm{H}_{2} \mathrm{SO}_{4} \text {-treated } \\
\text { Nematode-infected } \\
\text { Pine Substrate }\end{array}$ & $\begin{array}{l}31.5 \pm \\
2.97\end{array}$ & $\begin{array}{l}6.5 \pm \\
0.61\end{array}$ & $0.9 \pm 0.02$ & $28.5 \pm 0.33$ & $\begin{array}{l}6.0 \pm \\
0.59\end{array}$ & ND \\
\hline $\begin{array}{l}1 \% \mathrm{NaOH} \text {-treated } \\
\text { Nematode-infected } \\
\text { Pine Substrate }\end{array}$ & $\begin{array}{c}17.9 \pm \\
1.23\end{array}$ & $\begin{array}{c}14.3 \pm \\
1.12\end{array}$ & $0.9 \pm 0.05$ & $15.8 \pm 0.33$ & $\begin{array}{l}5.3 \pm \\
0.11\end{array}$ & ND \\
\hline $\begin{array}{c}\text { Water-treated } \\
\text { Nematode-infected } \\
\text { Pine Substrate }^{\mathrm{a}}\end{array}$ & $\begin{array}{l}25.3 \pm \\
2.04\end{array}$ & $\begin{array}{c}16.1 \pm \\
1.28\end{array}$ & $1.4 \pm 0.07$ & $31.5 \pm 0.29$ & $\begin{array}{l}6.4 \pm \\
0.61\end{array}$ & ND \\
\hline $\begin{array}{c}\text { Raw Distiller's } \\
\text { Grains }^{\text {b }}\end{array}$ & $\begin{array}{c}28.5 \pm \\
0.39 \\
\end{array}$ & $\begin{array}{l}13.1 \pm \\
0.17 \\
\end{array}$ & $4.2 \pm 0.20$ & - & $\begin{array}{l}5.1 \pm \\
0.12 \\
\end{array}$ & $\begin{array}{c}14.5 \pm \\
0.44 \\
\end{array}$ \\
\hline Corn Stover ${ }^{c}$ & 37.7 & - & - & 16.4 & - & - \\
\hline
\end{tabular}

Huang et al. (2020). "Nematode-infected pinewood," BioResources 15(4), 8403-8419. 8408 
The fungal hydrolysis that happened in the process of $F$. velutipes cultivation could lead to a lower percentage of polysaccharide content in the healthy pine substrate $(48.4 \%)$ when compared with the healthy pine sawdust $(54.2 \%)$. The lower lignin content percentage is helpful to reduce the blocking effect of the dense structure on the surface of the material and improve the conversion rate of the polysaccharide content (Zheng et al. 2018). However, the percentage of lignin content in the healthy pine substrate $(37.2 \%)$ was higher than that of healthy pine sawdust $(34.1 \%)$ due to the partial digestion of the polysaccharide content during the cultivation of $F$. velutipes, which indirectly increased the proportion of lignin content in the material. In addition, the percentage of polysaccharide content in the four kinds of materials $(54.2 \%, 51.4 \%, 48.4 \%$, and $50.2 \%)$ was higher than that of the common agricultural wastes such as corn straw (37.7\%) (Chen et al. 2016) and distiller's grains (41.6\%) (Zheng et al. 2015). Therefore, all four materials might have great potential to produce reducing sugar.

\section{Comparison of Reducing Sugar Production}

To find the optimal treatment conditions for reducing sugar conversion, this study used HPLC to analyze the yield of reducing sugar under different treatment conditions. As shown in Table 3, the alkali-treated reducing sugar content was not detectable. The reason may be that sodium hydroxide reacts chemically with the monosaccharides hydrolyzed by cellulose, resulting in a decrease in the yield of reducing sugars under high-temperature conditions (Zheng et al. 2015). The yield of reducing sugar after hot water treatment was also unsatisfactory. Only healthy pine sawdust $(4.8 \mathrm{~g} / \mathrm{kg})$ and nematode-infected pine sawdust $(13.5 \mathrm{~g} / \mathrm{kg})$ produced a small amount of reducing sugar. This may be due to the degradation of a small portion of the surface hemicellulose or cellulose (Pérez et al. 2008). Therefore, although water treatment has the advantages of low cost and no corrosion, it is not efficient enough for transforming woody cellulose.

Among the treatments, acid treatment showed a higher yield of reducing sugar due to the degradation of most of the hemicellulose; these results are similar to those in Salvinia molesta (Syaichurrozi et al. 2018). The yield of reducing sugar in all the substrates increased with the reaction temperature and acid concentration, especially at $121{ }^{\circ} \mathrm{C}$ with $4 \% \mathrm{H}_{2} \mathrm{SO}_{4}$ for $1 \mathrm{~h}$. The highest reducing sugar yield was obtained for healthy pine sawdust, nematode-infected pine sawdust, and healthy and nematode-infected pine substrate with $111.9 \mathrm{~g} / \mathrm{kg}, 236.8 \mathrm{~g} / \mathrm{kg}, 101.3 \mathrm{~g} / \mathrm{kg}$, and $137.2 \mathrm{~g} / \mathrm{kg}$, respectively. However, considering the cost of the reagents, instruments, and wastewater treatment costs, the most economical and effective treatment was $121{ }^{\circ} \mathrm{C}$ with $2 \% \mathrm{H}_{2} \mathrm{SO}_{4}$ for $1 \mathrm{~h}$. In this condition, it was found that the yield of reducing sugar from healthy $(97.7 \mathrm{~g} / \mathrm{kg})$ and nematode-infected pine substrate $(126.3 \mathrm{~g} / \mathrm{kg})$ were not higher than that of nematode-infected pine sawdust $(202.2 \mathrm{~g} / \mathrm{kg})$, probably because the polysaccharide content of nematode-infected pine substrate was digested by the fungi during the period of the infection by pinewood nematode. In addition, the polysaccharide content of healthy and nematode-infected pine substrate was digested by $F$. velutipes, resulting in a decrease in the yield of reducing sugar. However, the yield of reducing sugar from the nematode-infected pine substrate $(126.3 \mathrm{~g} / \mathrm{kg})$ was still higher than that obtained from the healthy pine sawdust $(98.6 \mathrm{~g} / \mathrm{kg})$ after acid hydrolysis. The results show that the nematode-infected pine substrate still has a great utilization value due to its capacity to be recycled to produce reducing sugar. Moreover, the obtained reducing sugar can be used as a cost-effective carbon source for cultivating microorganisms being of great benefit not only for the biopesticide manufacture but also for reducing agricultural waste (Wu et al. 2013; Zheng et al. 2015, 2018).

Huang et al. (2020). "Nematode-infected pinewood," BioResources 15(4), 8403-8419. 
Table 3. Yield of Reducing Sugar Under Different Treatment

\begin{tabular}{|c|c|c|c|c|c|c|c|}
\hline \multirow[b]{2}{*}{$\begin{array}{l}\text { Hydrolysis } \\
\text { Method }\end{array}$} & \multicolumn{3}{|c|}{ Parameter } & \multicolumn{4}{|c|}{ Yield of Reducing Sugar ( $\mathrm{g} / \mathrm{kg}$ ) } \\
\hline & $\begin{array}{c}\text { Temp. } \\
\left({ }^{\circ} \mathrm{C}\right)\end{array}$ & $\begin{array}{l}\text { Concen- } \\
\text { tration } \\
(\%)\end{array}$ & $\begin{array}{l}\text { Pres- } \\
\text { sure } \\
\text { (MPa) }\end{array}$ & $\begin{array}{l}\text { After } \\
\text { Treat. of } \\
\text { Healthy } \\
\text { Pine } \\
\text { Sawdust }\end{array}$ & $\begin{array}{c}\text { After } \\
\text { Treat. of } \\
\text { Healthy } \\
\text { Pine } \\
\text { Substrate }\end{array}$ & $\begin{array}{l}\text { After Treat. of } \\
\text { Nematode- } \\
\text { infected Pine } \\
\text { Sawdust }\end{array}$ & $\begin{array}{l}\text { After Treat. of } \\
\text { Nematode- } \\
\text { infected Pine } \\
\text { Substrate }\end{array}$ \\
\hline \multirow{8}{*}{$\begin{array}{c}\text { Acid } \\
\text { Hydrolysis }\end{array}$} & 121 & 0.5 & 0.5 & $\begin{array}{c}36.5 \pm \\
3.17^{\mathrm{e}}\end{array}$ & $\begin{array}{c}48.8 \pm \\
3.79 c\end{array}$ & $159.4 \pm 4.56^{d}$ & $42.3 \pm 4.15^{\mathrm{d}}$ \\
\hline & 121 & 1 & 0.5 & $\begin{array}{l}78.5 \pm \\
3.24^{\mathrm{c}}\end{array}$ & $\begin{array}{l}71.2 \pm \\
4.58^{\mathrm{b}}\end{array}$ & $\begin{array}{c}184.6 \pm \\
10.20^{c}\end{array}$ & $\begin{array}{c}113.0 \pm \\
10.63^{\mathrm{b}}\end{array}$ \\
\hline & 121 & 2 & 0.5 & $\begin{array}{c}98.6 \pm \\
6.67^{\mathrm{b}}\end{array}$ & $\begin{array}{c}97.7 \pm \\
9.71^{\mathrm{a}}\end{array}$ & $\begin{array}{c}202.2 \pm \\
15.34^{\mathrm{b}}\end{array}$ & $126.3 \pm 5.85^{a}$ \\
\hline & 121 & 4 & 0.5 & $\begin{array}{c}111.9 \pm \\
9.12^{\mathrm{a}}\end{array}$ & $\begin{array}{c}101.3 \pm \\
9.36^{\mathrm{a}}\end{array}$ & $236.8 \pm 9.96^{a}$ & $\begin{array}{c}137.2 \pm \\
10.51^{\mathrm{a}}\end{array}$ \\
\hline & 50 & 4 & 0.1 & $\mathrm{ND}^{*}$ & ND & $16.8 \pm 0.64^{\mathrm{e}}$ & ND \\
\hline & 100 & 4 & 0.1 & $\begin{array}{c}52.3^{ \pm} \\
4.45^{\mathrm{d}}\end{array}$ & $\begin{array}{l}81.2 \pm \\
6.53^{\mathrm{b}}\end{array}$ & $65.1 \pm 4.70^{\mathrm{e}}$ & $97.1 \pm 9.52^{\mathrm{c}}$ \\
\hline & 100 & 2 & 0.1 & - & $\begin{array}{c}25.3 \pm \\
1.37^{d} \\
\end{array}$ & - & $20.4 \pm 1.71^{\mathrm{e}}$ \\
\hline & 100 & 1 & 0.1 & - & $\begin{array}{l}9.0 \pm \\
0.75^{\mathrm{e}}\end{array}$ & - & $9.0 \pm 0.32^{\mathrm{e}}$ \\
\hline $\begin{array}{c}\text { Alkaline } \\
\text { Hydrolysis }\end{array}$ & 121 & 1 & 0.5 & ND & ND & ND & ND \\
\hline Water & 121 & - & 0.5 & $\begin{array}{l}4.8 \pm \\
0.22^{f}\end{array}$ & ND & $13.5 \pm 0.92^{f}$ & ND \\
\hline
\end{tabular}

\section{SEM Analysis}

It is well known that the nematode-infected pinewood can be infected also by fungi during the pine wilt disease (Mamiya 1983; Song 1993), and while the pinewood sawdust was used to cultivate $F$. velutipes, it will also be infected by fungi. To determine the effect of fungal infection during the period of pine wilt disease and its impact on mushroom cultivation and on the cell wall structure of the substrate, the morphology of the raw and the treated materials were analyzed by SEM. The surface structure of the raw healthy pine sawdust was smooth and compact; however, a rough and disordered surface appeared in the raw nematode-infected pine sawdust, as wells as the healthy and the nematode-infected pine substrate (Fig. 1). It can be observed that the fungus infection during the period of pine wilt disease and mushroom cultivation all can promote the hydrolysis of polysaccharide and lignin and destroy the original dense structure of the healthy pinewood under the optimal acid treatment $\left(121{ }^{\circ} \mathrm{C}, 2 \% \mathrm{H}_{2} \mathrm{SO}_{4}\right.$, and $\left.1 \mathrm{~h}\right)$. The surface of the four materials was disintegrated and contained a large number of holes and deep cracks as a result of a large amount of hydrolyzed hemicellulose. Chen et al. (2016) determined that the acid treatment of maize straw produced similar results. In addition, the structure of nematode-infected pine sawdust, healthy pine substrate, and nematode-infected pine substrate were more damaged when compared with healthy pine sawdust, probably due to the fact that the surface structure of healthy and nematode-infected pine substrate is predigested as a result of the infection, which makes them more sensitive to acid hydrolysis (Alexandropoulou et al. 2016). 

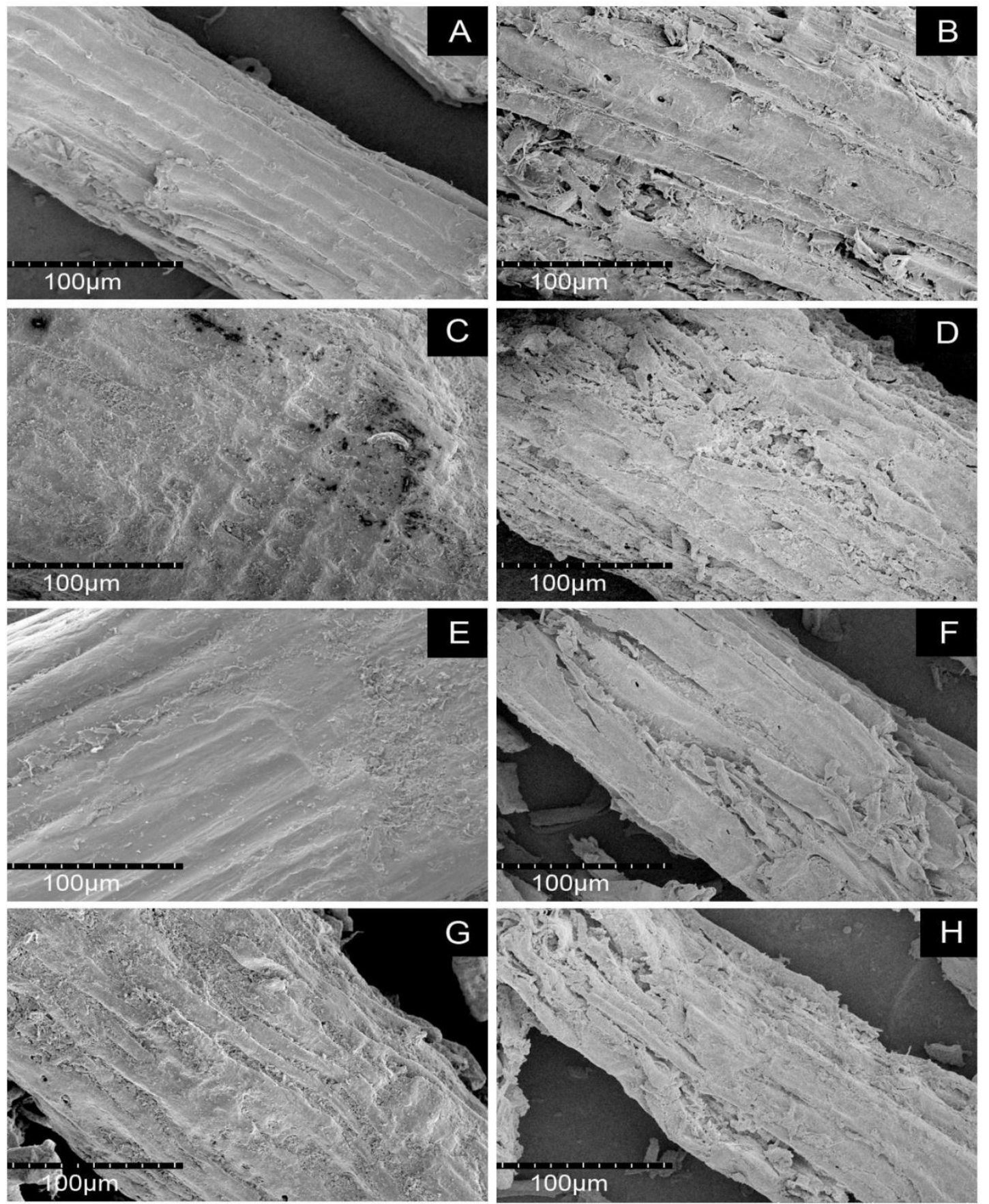

Fig. 1. SEM images of raw and treated materials: A: raw healthy pine sawdust, B: healthy pine sawdust with acid treatment, C: raw healthy pine substrate, D: healthy pine substrate with acid treatment, E: raw nematode-infected pine sawdust, F: nematode-infected pine with acid treatment, G: raw nematode-infected pine, $\mathrm{H}$ : nematode-infected pine substrate with acid treatment; acid treatment: $121^{\circ} \mathrm{C}, 2 \% \mathrm{H}_{2} \mathrm{SO}_{4}$, and $1 \mathrm{~h}$

Studies have shown that highly loose and chaotic surfaces contribute to the degradation of more quantities of cellulose and hemicellulose (Auxenfans et al. 2017). However, although the destruction degree of the surface structure of the nematode-infected pine substrate was higher than that observed from the nematode-infected pine sawdust, the 
yield of reducing sugar was the opposite due to a pre-degradation of the cellulose and hemicellulose during the cultivation of edible fungi which is consistent with previous studies (Chen et al. 2002).

\section{XRD Analysis}

Crystallinity is an important factor to demonstrate the compact structure of the material surface. In this study, the crystallinity of the four substrates was analyzed by XRD before and after the treatment. The strengths of the crystalline region (002) and the noncrystallized region (am) of the sample after fungal infection and acid hydrolysis were different (Fig. 2). The percentage of crystallinity in the healthy pine sawdust, healthy pine substrate, nematode-infected pine sawdust, and nematode-infected pine substrate was $51.5 \%, 49.6 \%, 48.1 \%$, and $50.1 \%$, respectively (Table 4 ). The crystallinity from the other three materials decreased slightly when compared with the crystallinity from the raw healthy pine sawdust. A possible explanation is that some cellulose degradation may occur in some crystalline regions during fungal infection (Sánchez 2009). After the acid hydrolysis $\left(121^{\circ} \mathrm{C}, 2 \% \mathrm{H}_{2} \mathrm{SO}_{4}\right.$, and $\left.1 \mathrm{~h}\right)$, the percentage of crystallinity in the healthy pine sawdust, healthy pine substrate, nematode-infected pine sawdust, and nematode-infected pine substrate increased to $62.1 \%, 60.5 \%, 56.8 \%$, and $58.1 \%$, respectively (Table 4 ). These results show that acid hydrolysis can effectively remove the xylan from the materials and then destroy the surface structure of the hemicellulose and lignin promoting more cellulose to be exposed to the acidic solution and finally converted into reducing sugar (Li et al. 2016). However, the increase of crystallinity from the nematode-infected pine sawdust and the nematode-infected pine substrate was smaller after acid hydrolysis, which may result from the fact that some of the biodegradable non-crystalline cellulose is digested during fungal infection.

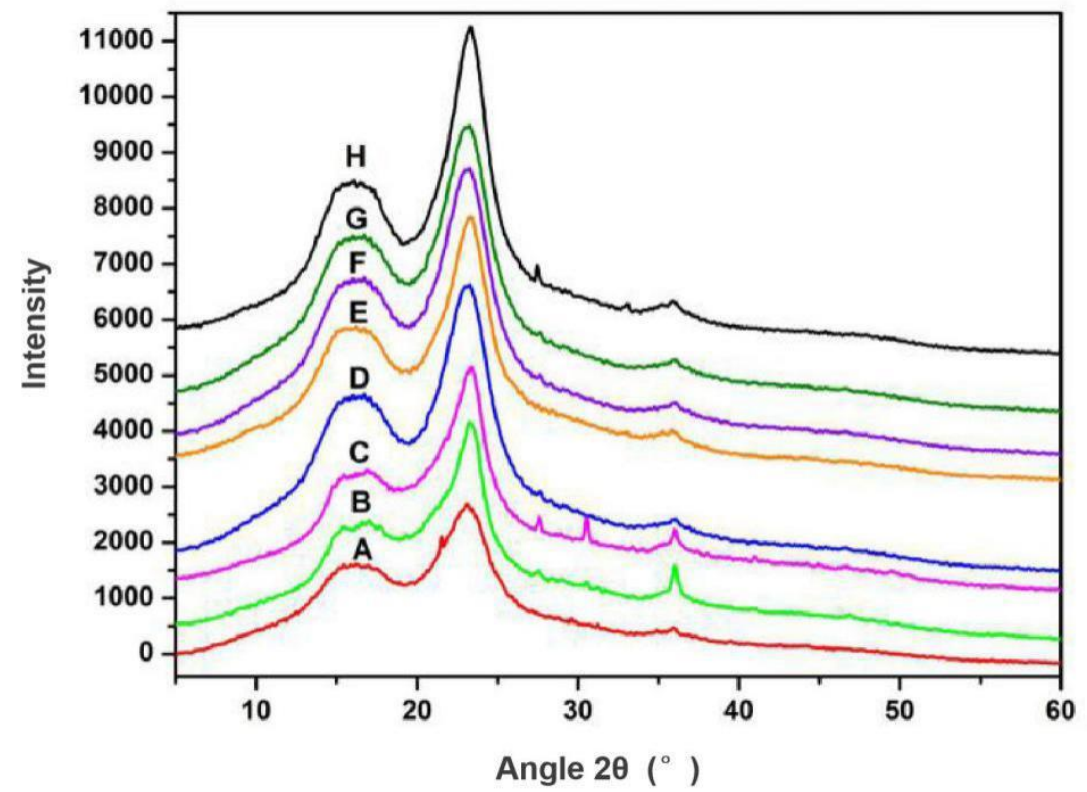

Fig. 2. XRD curves of raw and treated materials: A: raw nematode-infected pine sawdust, B: raw healthy pine substrate, C: raw nematode-infected pine substrate, D: raw healthy pine sawdust, $E$ : nematode-infected pine with acid treatment, F: nematode-infected pine substrate with acid treatment, G: healthy pine substrate with acid treatment, $\mathrm{H}$ : healthy pine sawdust with acid treatment; acid treatment: $121^{\circ} \mathrm{C}, 2 \% \mathrm{H}_{2} \mathrm{SO}_{4}$, and $1 \mathrm{~h}$ 
Table 4. Crystallinity of Raw and Acid Treated Substrates

\begin{tabular}{|c|c|c|}
\hline Sample & Treatment & $\mathrm{Crl}(\%)$ \\
\hline \multirow{2}{*}{ Healthy Pine Sawdust } & No treatment & $51.5 \pm 0.77$ \\
\cline { 2 - 3 } & $121^{\circ} \mathrm{C}, 2 \% \mathrm{H}_{2} \mathrm{SO}_{4}, 1 \mathrm{~h}$ & $62.1 \pm 0.95$ \\
\hline \multirow{2}{*}{ Healthy Pine Substrate } & No treatment & $49.6 \pm 1.86$ \\
\cline { 2 - 3 } & $121^{\circ} \mathrm{C}, 2 \% \mathrm{H}_{2} \mathrm{SO}_{4}, 1 \mathrm{~h}$ & $60.5 \pm 1.36$ \\
\hline \multirow{2}{*}{ Nematode-infected Pine Sawdust } & No treatment & $48.1 \pm 0.76$ \\
\cline { 2 - 3 } & $121^{\circ} \mathrm{C}, 2 \% \mathrm{H}_{2} \mathrm{SO}_{4}, 1 \mathrm{~h}$ & $56.8 \pm 0.64$ \\
\hline \multirow{2}{*}{ Nematode-infected Pine Substrate } & No treatment & $50.1 \pm 0.87$ \\
\cline { 2 - 3 } & $121^{\circ} \mathrm{C}, 2 \% \mathrm{H}_{2} \mathrm{SO}_{4}, 1 \mathrm{~h}$ & $58.1 \pm 0.55$ \\
\hline
\end{tabular}

\section{FTIR Analysis}

To determine the changes in the chemical structure of the substrates, FTIR was used to analyze the characteristic functional groups of the component surface (cellulose, lignin, and hemicellulose) before and after the sample treatment. The absorption spectra are shown in Fig. 3. The change in the absorption peak strength after the treatment is related to the change of the corresponding lignocellulose composition.

The absorption at $1458 \mathrm{~cm}^{-1}$ is related to the deformation of $\mathrm{CH}_{3}$ in the lignin, and the stretching vibrations of $\mathrm{C}=\mathrm{C}$ in the lignin are indicated by an absorptive peak 1509 $\mathrm{cm}^{-1}$. The absorption peak intensity from the healthy pine substrate, nematode-infected pine substrate, and nematode-infected pine sawdust at $1458 \mathrm{~cm}^{-1}$ and $1509 \mathrm{~cm}^{-1}$ was lower than in the healthy pine sawdust before the acid hydrolysis (Fig. 3), indicating that the fungal infection caused by pine wilt disease or the edible fungus could hydrolyze lignin content. Whereas acid hydrolysis can further degrade lignin content (Jordan et al. 2008), the absorption peak intensity of all samples decreased in the treated materials when compared with the untreated materials.

The absorptions at $1245 \mathrm{~cm}^{-1}$ and $1737 \mathrm{~cm}^{-1}$ are related to the alkyl ester of the acetyl group and non-conjugate stretching of $\mathrm{C}=\mathrm{O}$ in the hemicellulose, respectively. It can be seen that the peaks significantly decreased after fungal infection or acid hydrolysis compared with the peaks of raw healthy pine sawdust and raw healthy pine substrate (Fig. 3 ), suggesting that both fungal infection and acid treatment can effectively hydrolyze hemicellulose. It is worth noting that the absorption peak intensity of nematode-infected pine substrate and healthy pine substrate after acid hydrolysis was lower than that of nematode-infected pine sawdust after acid hydrolysis (Fig. 3), which indicates that hemicellulose in the sample of fungal infection combined with acid hydrolysis can be used more effectively.

The broad peak at $3000 \mathrm{~cm}^{-1}$ to $3500 \mathrm{~cm}^{-1}$ and the absorbance at $898 \mathrm{~cm}^{-1}$ represents the $\mathrm{O}-\mathrm{H}$ stretching and aliphatic or aromatic $\mathrm{C}-\mathrm{H}$ bonds, respectively. Compared with the raw healthy pine sawdust, the peak intensity of the nematode-infected pine sawdust, the healthy, and the nematode-infected pine substrate was decreased (Fig. 3), suggesting that the cellulose content of the digestible part of the fungal infection was consistent with the results of the previous component analysis. The peak strength of the four materials after acid hydrolysis decreased slightly at $3000 \mathrm{~cm}^{-1}$ to $3500 \mathrm{~cm}^{-1}$ and at $898 \mathrm{~cm}^{-1}$ (Fig. 3), suggesting that some cellulose contents were hydrolyzed during acid treatment, but the ability of acid to degrade cellulose was limited.

The absorptions at $2850 \mathrm{~cm}^{-1}$ and $2920 \mathrm{~cm}^{-1}$ are related to the stretching of the $\mathrm{CH}_{2}$ group on the surface of fatty extracts. The peak intensity of nematode-infected and healthy 
pine substrate was higher than corresponding raw materials (Fig. 3), which may have been because fungal infection decreased the proportion of surface extracts indirectly by decreasing the lignocellulose components. However, the peak strength of all samples after acid hydrolysis did not change significantly (Fig. 3), indicating that acid hydrolysis cannot remove fat extracts.

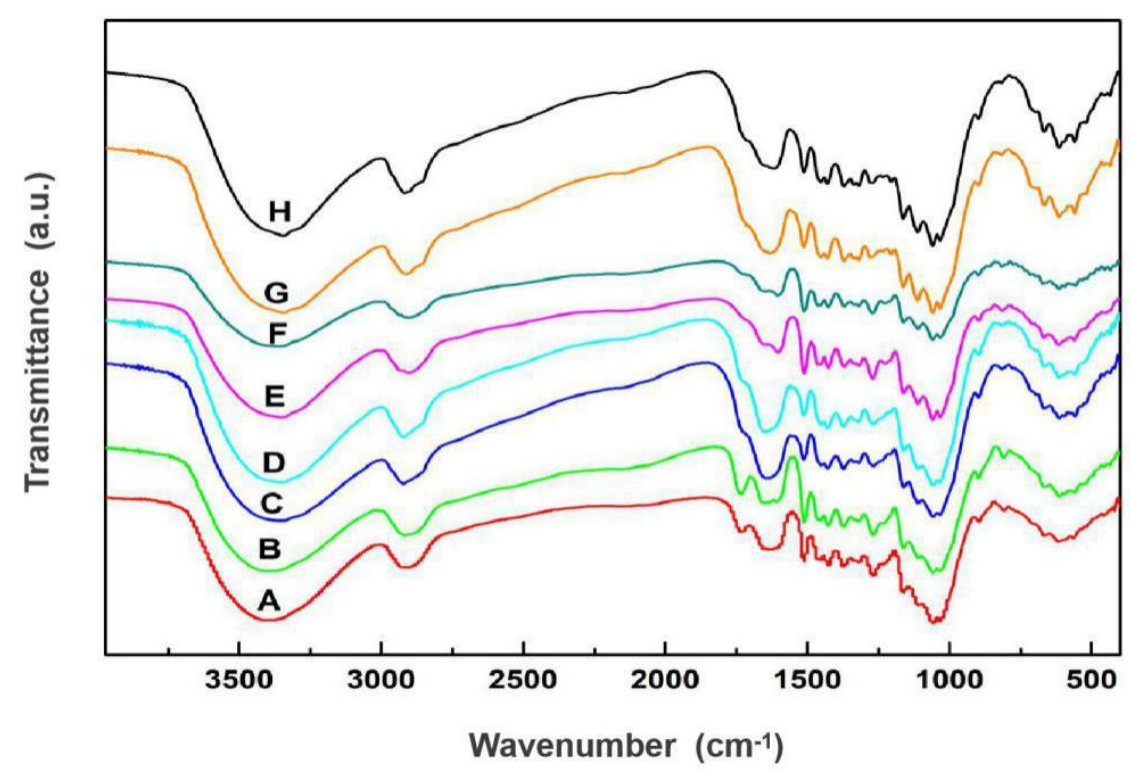

Fig. 3. FTIR curves of raw and treated substrates: A: raw nematode-infected pine sawdust, B: raw healthy pine sawdust, C: raw nematode-infected pine substrate, $D$ : raw healthy pine substrate, $E$ : nematode-infected pine with acid treatment, $F$ : healthy pine substrate with acid treatment, G: nematode-infected pine substrate with acid treatment, $\mathrm{H}$ : healthy pine sawdust with acid treatment; acid treatment: $121^{\circ} \mathrm{C}, 2 \% \mathrm{H}_{2} \mathrm{SO}_{4}$, and $1 \mathrm{~h}$

\section{XPS Analysis}

The XPS analysis can be used to obtain the characteristic information about polysaccharide, lignin, and extract on the sample surface. The $\mathrm{O} / \mathrm{C}$ ratio of the sample can reflect the composition ratio of the surface extract, lignin, and polysaccharide. Some studies have shown that the theoretical $\mathrm{O} / \mathrm{C}$ ratio of surface extracts, lignin, hemicellulose, and cellulose are 0.03 to $0.11,0.33,0.81$, and 0.83 , respectively (Laine et al. 1994). The peaks of $\mathrm{C} 1, \mathrm{C} 2$, and $\mathrm{C} 3$ in the $\mathrm{C} 1 \mathrm{~s}$ core level spectra are related to the three components of lignocellulose, respectively. The $\mathrm{C} 1$ peak consists mainly of the characteristic signals generated by $50 \%$ lignin content and most surface extract content. The characteristic signals generated by the $\mathrm{C} 2$ peak are mainly approximately $80 \%$ hemicellulose and $85 \%$ cellulose content. The C3 peak signal mainly comes from $20 \%$ hemicellulose and $15 \%$ cellulose content.

The $\mathrm{O} / \mathrm{C}$ value of raw healthy and nematode-infected pine substrate and nematodeinfected pine sawdust were lower than raw healthy pine sawdust (Table 5). Moreover, the corresponding $\mathrm{C} 1$ signature was increased in healthy and nematode-infected pine substrate and nematode-infected pine sawdust, when compared with raw healthy pine sawdust (Fig. 4) probably due to the effect of surface extracts (including fatty acids and waxes) in contributing to lower $\mathrm{O} / \mathrm{C}$ ratios. This indicates that some cellulose or hemicellulose content of healthy and nematode-infected pine substrate and nematode-infected pine sawdust is digested during the process of fungal infection, resulting in an increase in the 
proportion of surface lignin and extract (Ohgren et al. 2007). After acid hydrolysis, the O/C ratio in healthy pine sawdust, healthy pine, and nematode-infected pine substrate increased to $0.5,0.4$, and 0.42 , respectively, as a result of a small lignin degradation content after the acid hydrolysis (Samuel et al. 2010). While the O/C ratio of the acid-treated nematodeinfected pine substrate (0.37) was slightly lower than that of the raw nematode-infected pine substrate $(0.38)$, the result was contradictory with the effective degradation of the lignin content of the nematode-infected pine substrate by the acid treatment. However, considering the FTIR results, it can be hypothesized that the fungal infection can benefit the acid degradation of hemicellulose content, thus the proportion of lignin content in the material will increase. In addition, one of the contents of C2 and C3 in nematode-infected pine sawdust and healthy and nematode-infected pine substrate after acid treatment was decreased. However, compared with that in raw material, the contents of C2 and C3 in healthy pinewood were all increased after acid treatment, which also indicated that the content of hemicellulose of the material infected by fungus could be more effectively hydrolyzed in acid treatment.
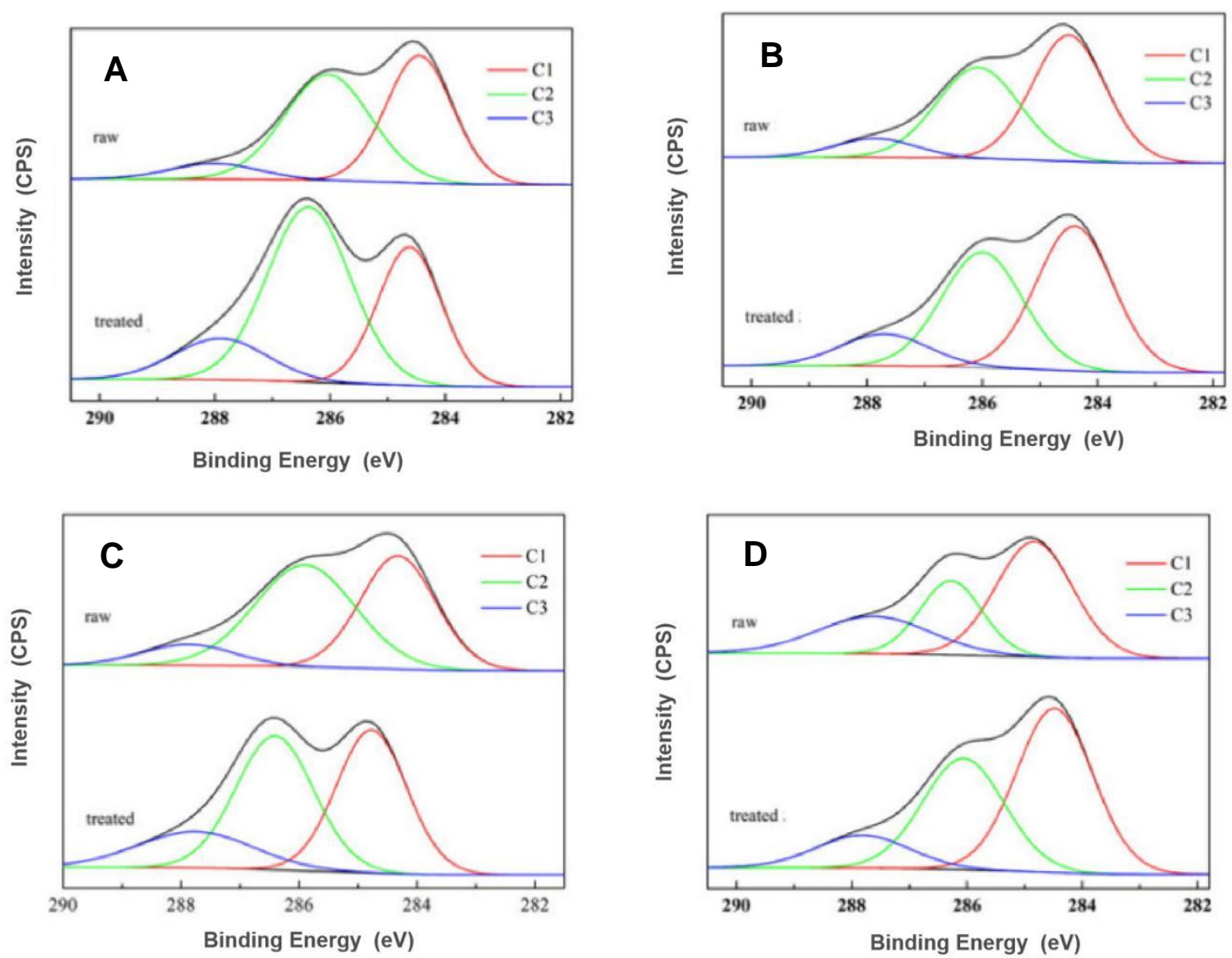

Fig. 4. C1s core level spectra of raw and treated materials: A: raw healthy pine sawdust and healthy pine sawdust with acid treatment, B: raw healthy pine substrate and healthy pine substrate with acid treatment, C: raw nematode-infected pine sawdust and nematode-infected pine sawdust with acid treatment, D: raw nematode-infected pine substrate and nematode-infected pine substrate with acid treatment; acid treatment: $121^{\circ} \mathrm{C}, 2 \% \mathrm{H}_{2} \mathrm{SO}_{4}$, and $1 \mathrm{~h}$ 
Table 4. XPS Analysis of Untreated and Different Treatments Samples

\begin{tabular}{|c|c|c|c|c|c|}
\hline \multirow{2}{*}{ Simple } & \multirow{2}{*}{ Treatment } & \multirow{2}{*}{ O/C Ratio } & \multicolumn{3}{|c|}{ C1s Signature } \\
\hline & & & $\mathrm{C} 1$ & $\mathrm{C} 2$ & C3 \\
\hline \multirow{2}{*}{$\begin{array}{l}\text { Healthy Pine } \\
\text { Sawdust }\end{array}$} & Raw & 0.40 & 44.6 & 48.3 & 7.1 \\
\hline & $121^{\circ} \mathrm{C}, 2 \% \mathrm{H}_{2} \mathrm{SO}_{4}, 1 \mathrm{~h}$ & 0.50 & 32.4 & 53.6 & 14.0 \\
\hline \multirow{2}{*}{$\begin{array}{l}\text { Healthy Pine } \\
\text { Substrate }\end{array}$} & Raw & 0.39 & 50.2 & 41.5 & 8.3 \\
\hline & $121^{\circ} \mathrm{C}, 2 \% \mathrm{H}_{2} \mathrm{SO}_{4}, 1 \mathrm{~h}$ & 0.40 & 47.6 & 40.2 & 12.2 \\
\hline \multirow{2}{*}{$\begin{array}{c}\text { Nematode-infected } \\
\text { Pine Sawdust }\end{array}$} & Raw & 0.40 & 46.8 & 44.0 & 9.2 \\
\hline & $121^{\circ} \mathrm{C}, 2 \% \mathrm{H}_{2} \mathrm{SO}_{4}, 1 \mathrm{~h}$ & 0.42 & 40.8 & 42.2 & 17.0 \\
\hline \multirow{2}{*}{$\begin{array}{c}\text { Nematode-infected } \\
\text { Pine Substrate }\end{array}$} & Raw & 0.38 & 50.3 & 26.1 & 23.6 \\
\hline & $121^{\circ} \mathrm{C}, 2 \% \mathrm{H}_{2} \mathrm{SO}_{4}, 1 \mathrm{~h}$ & 0.37 & 50.9 & 36.7 & 12.4 \\
\hline
\end{tabular}

\section{CONCLUSIONS}

1. This study showed that the nematode-infected pine sawdust is a good substrate for the cultivation of Flammulina velutipes, producing $126.3 \mathrm{~g} / \mathrm{kg}$ of reducing sugar under acid treatment $\left(2 \% \mathrm{H}_{2} \mathrm{SO}_{4}\right.$ at $121{ }^{\circ} \mathrm{C}$ for $\left.1 \mathrm{~h}\right)$.

2. The study can conclude that the fungal infections that happened in the period of pine wilt disease and during the cultivation of $F$. velutipes both can promote acid treatment to degrade hemicellulose content by comparing the yield of reducing sugar and the change of surface structure characteristics of nematode-infected and healthy pine sawdust, nematode-infected, and healthy pine substrate.

3. While fungal infection that happened in the period of pine wilt disease can also contribute to the degradation of the polysaccharide content, it was demonstrated that the degradation of polysaccharides in nematode-infected pine sawdust can be used for the efficient cultivation of $F$. velutipes, which can improve the recycling value of nematode-infected pinewood.

4. In the future, optimization of the treatment method of the nematode-infected pinewood for cultivation of $F$. velutipes on the basis of this study and testing new $F$. velutipes varieties can also be tested to contribute in breaking the bottleneck of using pinewood for cultivation.

\section{ACKNOWLEDGMENTS}

The authors are grateful for the support by the National Key Research and Development Project (2017YFD0600105), the National Natural Science Foundation of China (KAA19083A, 31601905), the Fujian Agriculture and Forestry University Outstanding Master thesis Fund (1122YS01002), the Fujian Science and Technology Department Natural Science Foundation(2016J01097), the Fujian Science and Technology Plan Project (2018N5002), the Fujian Agricultural and Forestry University Scientific Research Fund (xjq201614), the Fujian Agricultural and Forestry University Forestry College Forest Science Peak Discipline Project (71201800720,71201800753, and 71201800779), the Fujian College Student Innovation and Entrepreneurship Training Program Project (201810389102), and the Fujian Forestry Science Research Project 
(Minlinke (2017) 03, Minlinke (2020) 601). Additionally, the authors would like to thank XiaoGe Xing, ShiYing Zhang, Qin Zhang, and YueTing Xiong, for their valuable help.

\section{REFERENCES CITED}

Alexandropoulou, M., Antonopoulou, G., Fragkou, E., Ntaikou, I., and Lyberatos, G. (2016). "Fungal pretreatment of willow sawdust and its combination with alkaline treatment for enhancing biogas production," Journal of Environmental Management 203(2), 704-713. DOI: 10.1016/j.jenvman.2016.04.006

Auxenfans, T., Crônier, D., Chabbert, B., and Paës, G. (2017). "Understanding the structural and chemical changes of plant biomass following steam explosion pretreatment," Biotechnology for Biofuels 10(1), Article number 36. DOI: 10.1186/s13068-017-0718-Z

Chen, L. J., Li, J. B., Lu, M. S., Guo, X. M., Zhang, H. Y., and Han, L. J. (2016). "Integrated chemical and multi-scale structural analyses for the processes of acid pretreatment and enzymatic hydrolysis of corn stover," Carbohydrate Polymers 141, 1-9. DOI: 10.1016/j.carbpol.2015.12.079

Chen, S. Y., Wu, Q. P., Xiao, Y., Gue, S. H., and Qiu, W. Y. (2002). "Review of studies of cultivation edible fungi with conifer chips," Microbiology 29(2), 49-52.

Chen, Y., Wang, L. F., Plao, C. G., Zhu, T. H., Shen, S. C., and Zheng, Y. Z. (2008). "Screening of wood-rotting fungi to treat stumps of dead pine trees caused by PWN (Bursaphelenchus xylophilus)," Forest Research 21(4), 548-554. DOI: 10.1016/S1872-2040(08)60061-4

Gan, Y. J., Zhang, Y. Z. H., and Hong, P. (2010). "Automatic control system and the process design of the heat treatment about pine wood nematode infected timber," Biomass Chemical Engineering 44(5), 41-44.

GB/T 742 (2008). "Fibrous raw material, pulp, paper, and board- Determination of ash," Standardization Administration of China, Beijing, China.

GB/T 2677.2 (2011). "Determination of moisture content in fibrous raw material," Standardization Administration of China, Beijing, China.

Jiang, P., Zhao, J. N., Chai, X. M., Wu, Z. L., and He, Z. H. (2001). "Integrated control techniques of Bursaphelenchus xylophilus," Journal of Zhejiang Forestry Science \& Technology 21(4), 1-6.

Jiang, L. Y., Sheng, C. S., Ma, S. G., Wang, L., and Shi, J. (2006). "Study on processing timber infected with pine wood nematode using microwave," Journal of Nanjing Forestry University, 30(6), 87-90.

Jordan, S. N., Mullen, G. J., and Murphy, M. C. (2008). "Composition variability of spent mushroom compost in Ireland," Bioresource Technology 99(2), 411-418. DOI: 10.1016/j.biortech.2006.12.012

Kuroda, K. (1989). "Terpenoids causing tracheid-cavitation in Pinus thunbergii infected by the pine wood nematode (Bursaphelenchus xylophilus)" Annals of the Phytopathological Society of Japan 55(1), 170-178. DOI: 10.3186/jjphytopath.55.170

Laine, J., Stenius, P., Carlsson, G., and Ström, G. (1994). "Surface characterization of unbleached kraft pulps by means of ESCA," Cellulose 1(2), 145-160. DOI: 10.1007/BF00819664

Lara, V., Beata, K. T., Stefan, W., Jarl, H., Annele, H., Kari, S., and Marj, T. (2010). "Scots pine (Pinus sylvestris) bark composition and degradation by fungi: Potential 
substrate for bioremediation," Bioresource Technology 101(7), 2203-2209. DOI: 10.1016/j.biortech.2009.11.052

Li, P., Cai, D., Luo, Z., Qin, P., Chen, C., Wang, Y., Zhang, C., Wang, Z., and Tan, T. (2016). "Effect of acid pretreatment on different parts of corn stalk for second generation ethanol production," Bioresource Technology 206(19), 86-92. DOI: 10.1016/j.biortech.2016.01.077

Lu, M., Yan, Q. L., Chi, Y., Zheng, H. Y., and Xiao, L. J. (2016). "Production of liquid spawn of an edible mushroom, Sparassis latifolia by submerged fermentation and mycelial growth on pine wood sawdust," Scientia Horticulturae 209, 22-30. DOI: 10.1016/j.scienta.2016.06.001

Mamiya, Y. (1983). "Pathology of the pine wilt disease caused by Bursaphelenchus xylophilus," Annual Review of Phytopathology 21(1), 201-220. DOI: 10.1146/annurev.py.21.090183.001221

Ohgren, K., Bura, R., Saddler, J., and Zacchi, G. (2007). "Effect of hemicellulose and lignin removal on enzymatic hydrolysis of steam pretreated corn stover," Bioresource Technology 98(13), 2503-2510. DOI: 10.1016/j.biortech.2006.09.003

Pérez, J. A., Ballesteros, I., Ballesteros, M., Sáez, F., Negro, M. J., and Manzanares, P. (2008). "Optimizing liquid hot water pretreatment conditions to enhance sugar recovery from wheat straw for fuel-ethanol production," Fuel 87(17), 3640-3647. DOI: 10.1016/j.fuel.2008.06.009

Samuel, R., Pu, Y., Raman, B., and Ragauskas, A. J. (2010). "Structural characterization and comparison of switchgrass ball-milled lignin before and after dilute acid pretreatment," Applied Biochemistry and Biotechnology 162(1), 62-74. DOI: 10.1007/s12010-009-8749-y

Sánchez, C. (2009). "Lignocellulosic residues: Biodegradation and bioconversion by fungi," Biotechnology Advances 27(2), 185-194. DOI: 10.1016/j.biotechadv.2008.11.001

Shi, J., Luo, Y. Q., Wu, H. W., Kari, H., and Liang, L. Z. (2008). "Impact of the invasion by Bursaphelenchus xylophilus on forest growth and related growth models of Pinus massoniana population," Acta Ecologica Sinica 28(7), 3193-3204. DOI: 10.1016/S1872-2032(08)60068-2

Sluiter, A. R. R., Scarlata, C., Sluiter, J., and Templeton, D. (2008). Determination of Extractives in Biomass (NREL/TP-510-42618), National Renewable Energy Laboratory, Golden, CO, USA.

Song, Y. S., Zang, X. Q., Liu, Y., Ge, M. G., and Zhao, J. L. (1994). "Study on the effect of fumigation on the wood infested by pine wood nematode with methyl bromide," Forestry Scientific Research 7(6), 671-676.

Song, Y. S. (1993). "Visual examination of diseased wood of pine wood nematode," Plant Quarantine 7(1), 23-25.

Syaichurrozi, I., Kurnia Villta, P., Nabilah, N., and Rusdi, R. (2018). "Effect of sulfuric acid pretreatment on biogas production from Salvinia molesta," Journal of Environmental Chemical Engineering 7(1), Article ID 102857. DOI: 10.1016/j.jece.2018.102857

Wu, S., Lan, Y., Wu, Z., Peng, Y., Chen, S., Huang, Z., Xu, L., Gelbič, I., Guan, X., and Zhang, L. (2013). "Pretreatment of spent mushroom substrate for enhancing the conversion of fermentable sugar," Bioresource Technology 148(8), 596-600. DOI: 10.1016/j.biortech.2013.08.122 
Wu, Y. Z. (2013). “A preliminary study on cultivation of Poria cocos on nematode affected pine wood," Journal of Fujian Forestry Science and Technology 2013(4), 51-55.

Yu, R. L., Qin, X. S., and Song, F. G. (2004). "The survey of Flammulina velutipes research," Acta Edulis Fungi 11(4), 63-68.

Zhao, X., Luo, K., Zhang, Y., Zheng, Z., Cai, Y., Wen, B., Cui, Z., and Wang, X. (2017). "Improving the methane yield of maize straw: Focus on the effects of pretreatment with fungi and their secreted enzymes combined with sodium hydroxide," Bioresource Technology 250, 204-213. DOI: 10.1016/j.biortech.2017.09.160

Zheng, Q., Lin, B., Zhang, Q., Wu, S., Wang, S., He, X., Wang, Y., Guan, X., and Huang, X. (2015). "Treating distillers' grain from the Luzhou aroma/flavor industry to degrade fiber," Energy \& Fuels 29(7), 4305-43107. DOI: 10.1021/acs.energyfuels.5b00250

Zheng, Q., Zhou, T., Wang, Y., Cao, X., Wu, S., Zhao, M., Wang, H., Xu, M., Zheng, B., and Zheng, J. (2018). "Pretreatment of wheat straw leads to structural changes and improved enzymatic hydrolysis," Scientific Reports 8(1), Article number 1321. DOI: 10.1038/s41598-018-19517-5

Article submitted: April 26, 2020; Peer review completed: June 28, 2020; Revised version received: July 27, 2020; Accepted: September 13, 2020; Published: September 18, 2020. DOI: $10.15376 /$ biores.15.4.8403-8419 